\title{
Examining Dentistry College Students' Recognition of the Semantic/ Pragmatic Functions of Hedges in English Scientific Writing
}

Heevi Khaled Jamel

\author{
Department of English, Duhok University, Kurdistan Region, IRAQ
}

\begin{abstract}
One of the most important characteristics of English scientific writing is the use of cautious language, known as "hedging". A proper awareness of hedges uses and function is crucial to scientific precision, scientific integrity, and author-reader relationship. However, dentistry college students face difficulties in recognizing hedging devices in academic writing. The present study aims at examining the recognition of a scientific college final year students of the semantic/ pragmatic functions of hedges in scientific English writing to answer the research question concerning their ability to perform satisfactorily in such a sensitive area as that of science, bearing in mind that they are supposed to be advanced students who have been instructed in scientific English for five years. For that purpose, final year students of the academic year 2020-2021, from the College of Dentistry were chosen. The total number of participants was 71 students. The study followed the quantitative method for its design, used as its instrument a close-ended questionnaire, and employed the SPSS for data analysis. The study showed that the students did not perform satisfactorily; a finding which calls for concern and implies that an explicit instruction in English scientific writing is needed. The study concluded that more attention should be paid to the teaching of this linguistic aspect in scientific English in order to prepare students to better deal with the requirements of academic/ scientific writing.
\end{abstract}

KEYWORDS: hedging, hedging devices, semantic/ pragmatic function of hedges.

\section{Introduction: Theoretical Background}

\subsection{Hedging: An Overview of the Development of} the Term

Originally Speaking, the concept of hedging was proposed by Lakoffian semantically oriented approach (1975). Hedges are "words whose meaning implicitly involves fuzziness [and] whose job is to make things fuzzier or less fuzzy"(1973, p. 471). By this definition, they involve both intensifiers and de intensifiers. Examples of the former are "very" and "really", and the later are "sort of" and "somewhat". The reason behind the notion of "fuzziness" is that natural language concepts cannot be interpreted as true, false, or non-sense, which is a common practice in formal logic for the purpose of interpreting natural language (Lakoff, 1973, pp. 468-469). Consequently, category membership is seen as gradable with hedges demonstrating effectively this gradability. However, the Lakoffian view of hedges fell short of completely explaining the internal functioning of hedges. Therefore, the concept started to be seen as pragmatically motivated, context sensitive linguistic device (Adamczyk, 2015, p. 323). Seen from the pragmatic perspective, the term 'Hedged Performative' was given by Fraser (1975, pp. 187-210) to sentences that are performative in form and maybe regarded as "the performance of illocutionary act" hedged in the main verb, as in the following examples (p. 187):

"I can promise you that we will be there on time".

"I must advice you to remain quiet".

"I have admitted that you have a point".

These examples can be regarded as the performance of the "illocutionary act" made by the performative verb, and the modals as hedges (Fraser, 1975, pp. 187-210). Further progress was made by Brown and Levinson (1978), who adopted the speech act of hedging. They described hedges as "a particle, word or phrase that modifies the degree of membership of a predicate or a noun phrase in a set; it says of that membership that it is partial or true only in certain respects, or that it is more true and complete than perhaps might be 
expected" (p. 145). This description provides a double role of a hedge, where by attenuating or enhancing the strength of the speech act can be used as a technique to reduce the threat to face and so indicate politeness. Thus, one can safely make one's view uncertain by the use of hedging, such as kind of, sort of as in "I really sort of think/hope/wonder" (Brown \& Levinson 1978, p. 116).

Prince et al. (1982, pp. 83-97) provided and clarified a major contrast between two sorts of hedging: (a) Approximators which influence "the propositional content" and the true state of the propositions are described as propositional hedging, and (b) Shields "which affect the degree and type of the speaker commitment". Indeed, this view was criticized as being fully inadequate. Skelton (1988, p. 38) figured out that the classification is sustainable only in the "abstract". He noted that approximators may act as shields easily. More recently, the concept of Prince et al. (1982) has been adapted to a modal made by Caffi (2007, p. 102) who distinguished between bushes, hedges, and shields in her mitigation technique framework. Caffi stated that hedges include both "speaker commitment" and indication of "illocutionary force"(p. 104).

After Lakoffs' discovery, the issue generated a lot of curiosity and gave rise to a lot of studies. Clemen (1997, p. 235) stated that hedging is "achieved primarily by setting utterances in a context rather than by straightforward statement, or that discourse analysis must precede semantic grasp". Hedges are “determined by context (type of discourse),

the colloquial situation and the speaker's/writer's intention, plus the background knowledge of the interlocutors" (Clemen, 1997, p. 243). Therefore, hedging can be inferred only from the mixture of the specific clausal item with the related illocution.

\subsection{Hedging in Academic/Scientific Writing: Definition and Significance}

Among the most crucial elements of academic writing is the extent to which the authors attempt to improve the claims they make, toning down questionable or risky claims, convey what they consider to be correct, and express their attitudes (Hyland, 2000). All such expressions of doubt and uncertainty are defined as hedges. A number of studies (See for example Hyland, 1996b; Meyer, 1997; Cabaness, 2007; and Banks, 1998) have proved that the use of hedging devices permits authors to express their convictions and how to convey them to their readers .In this regard, Hyland (1995, p. 33) defined hedges as "the expression of tentativeness and possibility in language use and it is crucial to scientific writing where statements are rarely made without subjective assessments through stating unreliable cases". Thus, hedges enable authors to express their stance regarding the truthfulness of the statements they make and predict potential objections. Consequently, they show "unproven claims and cautiously soften categorical assertion" (Hyland, 1995, p. 33). Advocating a rather similar view, Hyland (1996, p. 2) suggested that hedging is a language technique "expressing possibility rather than certainty" and is primarily an aspect of "persuasion, caution and modesty" in scientific writing.

In support of the above-mentioned claim, Fraser (2010) extended hedging to all types of writing where there is a lack of full commitment and suggested that the use of hedging devices affects the meaning of the utterance. For instance, in

"The pool has sort of an L-shaped design".

"Peter's house is almost 100 feet wide".

The commitment to a pool with a real L- model and to a Peter's house with a diameter of 100 feet is attenuated (Fraser, 2010, pp. 201-202).

Salager-Meyer (1997) claimed that hedges can be seen as the key feature that acts as a link between the texts propositional content and the factual understanding of the authors. He maintained that authors use hedging in order: 1. to reduce the risk of "opposition" and "minimize" the "threat to face that occurs behind the 
act of communication; 2. to report results in a more precise manner; 3 . to express positive or negative politeness; and 4. to abide by an "established writing style" (Salager-Meyer, 1997, pp. 128-131).

Banks (1998, p. 7) suggested three reasons behind the use of hedges: 1. expressing "incomplete or inconclusive data"; 2 adhering to the style of scientific writing; and 3. avoiding a behavior that is facethreatening.

Hedging devices are viewed by Varttala (2001, p. 68) as a technique by which authors show that they have addressed the limits of their own writing process and they have addressed their own procedure in a critical manner, cautiously showing to the reader how well their account can be shown to correspond to facts. It seems that this understanding is the dominant one in research articles as it provides a strong relation between the linguistic technique of hedging and the social quality of scientific knowledge-making.

Cabanes (2007, p. 139) explained that authors of academic texts resort to hedging in order to: firstly, show deference and politeness; secondly, avoid the adverse consequences if they happen to be proved wrong; and finally, to achieve the needed precision in writing. Additionally, Tatiana (2019, p. 98) brought forward some general functions for using hedging: 1.to limit a certain proposition's truth value with regard to the opinions and judgments of the speakers; 2 . to shift responsibility; 3 . to attenuate the effect of the speech act; 4 . to mitigate the proposition; and 5. to support the statements with facts and statistics.

Mahmood (2018, p. 26) mentioned that the significance of hedges stems from the fact that they fulfill three functions. Firstly, hedges are used to comment on the proposition's content in order to achieve accuracy and at the same time avoid the reader's rejection of the arguments. Secondly, hedges facilitate the expression of confidence towards the proposition to varying degrees. Thirdly, hedges help establish and maintain the relationship between authors and their readership.
In the context of this study, hedges fulfill a semantic as well as a pragmatic function. On the one hand, they are used to comment on the truthfulness and precision of the conceptual content of a proposition, thus fulfilling what Halliday (1978) calls the ideational function of language in terms of its experiential component which is regarded as the "'content' function of language; ... language as the expression of the process and other phenomena of external world" (Halliday, 1978, p. 48). On the other hand, they are used to maintain the social interaction between the participants, thus fulfilling what Halliday (1970 \& 1978) calls the interpersonal function of language.

\subsection{Classification of Hedging Devices}

Hedging devices have been classified by many scholars, such as Hayland (1996a, 1996b) and Varttala (2001). Salager-Meyer's (1997) classification, however, represents the most commonly used hedges in scientific writing in English. Her classification runs as follows (pp. 131-133).

- Modal auxiliary verbs, e.g., may, might, can, could, would, and should.

- Modal lexical verbs (speech act verbs); these verbs are used to perform the acts such as doubting and evaluating rather than merely describing the variation degree of illocutionary force, e.g., to appear, to believe, to assume, to suggest.

- Adjectival, adverbial, and nominal modal phrase:

- Probability adjectives, e.g., possible, probable, un/like.

○ Nouns, e.g., assumption, claim, possibility, estimate, suggestion.

- Adverbs (that can be regarded as non-verbal modals), such as perhaps, possibly, probably, likely, virtually, apparently.

- Approximators (quantity, frequency and time), e.g., approximately, roughly, about, often, occasionally, generally, usually, somewhat, somehow. 
- Introductory phrases, such as I believe, to our knowledge, it is our view that, we feel that, which reveal the author's personal doubt and direct involvement.

- If clauses, such as if true, if anything.

- Compound hedges. Phrases that are made up of several hedges, e.g.,

- a modal auxiliary combined with a lexical verb with a hedging content as it would appear.

- a lexical verb followed by a hedging adverb or adjective that reinforces the hedges already inherent in the lexical verb, e.g.,it seems reasonable/ probable, it may suggest that, it seems likely that, it would indicate that.

\section{Research Question}

This study tries to investigate the following question: Are final year students (or senior students according to the American system of education) of such a scientific college like the College of Dentistry able to recognize the semantic/ pragmatic functions of hedges in English scientific writing satisfactorily, bearing in mind they are supposed to be advanced students who have been instructed in scientific English for five years?

\section{Previous Studies}

Many studies have been carried out on hedges. Salager-Meyer (1994), for example, examined the frequency of the use of hedges in fifteen English medical papers. Hyland (1994, 1995, 1996a, 1996b, 1998, 2000, and 2008) investigated at length the use of hedging devices, how they are expressed and their function in academic/ scientific writing. Varttala (2001) investigated the variation in the frequency of hedges in accordance with discipline and intended audience. In 745 scholarly essays, Hinkel (2005) compared the frequencies of use of hedging devices between native speakers and non-native speakers of English. Martin-Martin (2008) analyzed the data and extent of hedges in forty published studies in the area of clinical and health psychology published in English and Spanish. He concluded that although these two languages have many points in common, a slight higher tendency was reported in English research papers. Rabab'ah (2013) in his study has worked on how and why hedges are used in nursing and education academic research articles. The results showed that there were significant differences between education and nursing writers' use of hedging devices in favor of the education writers. This indicates that writers of education articles use hedging more frequently than the writers of nursing articles.

As far as the recognition and perception of hedges in English academic writing is concerned, the researcher has been able to find two studies which dealt with this topic. The first one was by Mukheef (2012) who investigated the knowledge and use of Iraqi EFL learners of hedging devices. The sample consisted of (100) fourth year college students, academic year (2008- 2009), departments of English at the colleges of Education, Universities of Babylon and AL-Qadisiysa. They were tested for recognition and production. For the purpose of recognition, they were given two tasks; in the first one, they were asked to underline hedges in ten sentences, and in the second one, they were given fifteen sentences and asked to decide whether they are hedged or not. The researcher found out that their identification of hedges was poor, with a total rate of incorrect responses $(1395,27.9 \%)$ as compared to correct ones $(1105,22.1 \%)$.The researcher noted that hedging is an area that is often overlooked in teaching English as a foreign language.

Another study was carried out by Lee (2020) who compared native and non-native (Korean) English speakers' perception and production of hedges and boosters. As far as perception of hedges is concerned, the study's participants were 47 American English speakers and 55 Korean college students fluent in English academic reading. The results of the study showed that both the native and the non-native English speakers' perception patterns were similar, 
with some exceptions. A major weakness of the study though is that the questions used in the survey displayed the same pattern throughout. Two statements were given to each question: a hedged one (target) and a non-hedged one (neutral), e.g., Target: Global warming is serious, I believe. (2) Neutral: Global warming is serious. It is the present researcher's understanding that this uniformed pattern has a high predictability value. Accordingly, the findings of the study seem to be highly predictable because of the construction of the questionnaire. So is the similarity in perception patterns real or due to the presence of the uniformed pattern in the questionnaire?

The conclusions that can be drawn so far are that the use of hedges is very important in English scientific writing because they help understand the conceptual content of a proposition with precision and develop a positive attitude towards the author. The other point is that dentistry students face difficulties in recognizing hedging devices.

\section{Methodology}

\subsection{Participants}

The participants in this study were 71finalyear students of the academic year (2020-2021) from the College of Dentistry, University of Duhok. The students participated voluntarily in this study. The sample was chosen from a scientific college and its students were about to graduate and practice dentistry so as be, engaged in further reading in their specialization, and probably pursue their postgraduate studies which require them to read and evaluate English scientific material in order to write research papers, theses, and even dissertations.

\subsection{Instrument}

The instrument used is a closed-ended questionnaire that consisted of 18 statements in the form of sentences taken from English scientific writing. The classification of Salager-Meyer (1997, pp. 131-133) was followed in the random choice of hedging devices by the researcher. Compound hedging devices, which can be double, treble, or quadruple, were not included. Only single hedging devices were selected because of the researcher's concern that compound hedging devices might have a high predictability value, which warrants another study with a different objective.

The researcher asked the students to read the statements carefully and to decide whether the author was certain or uncertain. The assumption is that when the students read the statements, they will be engaged in understanding the conceptual content of the proposition but will also be required to decide on the author's stance regarding the truthfulness or precision of the proposition in question. Therefore, there is an interplay between the semantic and the pragmatic functions. Fourteen statements indicated uncertainty and four statements $(3,8,13$, and 18) indicated certainty. The high number of the former type of statements is attributed to the fact that the major concern of the researcher is the use of hedges to indicate uncertainty. The 'certain' option was included to secure its validity. Below is the questionnaire (see appendix A).

\section{Research Design}

This study adopted the quantitative method for its design, the descriptive type. Data collection was based on the research instrument, namely the abovementioned questionnaire, which was distributed to the participants in order to gather the necessary information to answer the research question.

\section{Data Analysis}

The data obtained from the close-ended questionnaire were analyzed by using the computer programme (SPSS), the Statistical Package for Social Sciences (SPSS) version 25. The analysis provided descriptive statistics, in the form of tables for the Mean, Standard Deviation (STD), Frequency, and Percent. It also provided inferential statistics in the form of tables for the ANOVA test and the Post Hoc test - Scheff. 


\section{Descriptive Tables}

From table 1, it is concluded that:

- The highest correct answer percentage was towards if clause (63.4\%) with a high mean (1.63), while the error answer percentage was (36.6\%) towards the same situation. This indicates that the respondents are more accurate in terms of (if clause) than the others.

- The lowest correct answer percentage was towards believe (29.6\%) with a low mean (1.28), while the error answer percentage was (70.4\%) towards the same situation. This indicates that the respondents' accuracy in terms of (believe) is the lowest among the others.

- The total percent for Error in the 'uncertain' group was $(51.3 \%)$, and for Correct was $(48.7 \%)$, so this indicates that the participants in the study do not recognize uncertainty in the correct way.

Table 1: 'Uncertain' Group Descriptive Statistics

\begin{tabular}{|c|c|c|c|c|c|}
\hline & & Mean & STD & Frequency & Percent \\
\hline \multirow{2}{*}{ Might } & Error & 1.50 & 0.577 & 39 & 54.9 \\
\hline & Correct & 1.45 & .0501 & 32 & 45.1 \\
\hline \multirow{2}{*}{ Could } & Error & 1.50 & 0.577 & 31 & 43.7 \\
\hline & Correct & 1.57 & 0.499 & 40 & 56.3 \\
\hline \multirow{2}{*}{ Seem } & Error & 1.50 & 0.577 & 43 & 60.6 \\
\hline & Correct & 1.39 & 0.491 & 28 & 39.4 \\
\hline \multirow{2}{*}{ Appear } & Error & 1.25 & 0.500 & 44 & 62.0 \\
\hline & Correct & 1.39 & 0.491 & 27 & 38.0 \\
\hline \multirow{2}{*}{ About } & Error & 1.50 & 0.557 & 40 & 56.3 \\
\hline & Correct & 1.43 & 0.499 & 31 & 43.7 \\
\hline \multirow{2}{*}{ Generally } & Error & 1.50 & 0.500 & 29 & 40.8 \\
\hline & Correct & 1.60 & 0.494 & 42 & 59.2 \\
\hline \multirow[b]{2}{*}{ Possibly } & Error & 1.50 & 0.577 & 33 & 46.5 \\
\hline & Correct & 1.54 & 0.502 & 38 & 53.5 \\
\hline \multirow{2}{*}{ Probably } & Error & 1.75 & 0.500 & 32 & 45.1 \\
\hline & Correct & 1.54 & 0.502 & 39 & 54.9 \\
\hline \multirow{3}{*}{ Believe } & Error & 1.50 & 0.500 & 50 & 70.4 \\
\hline & Correct & 1.28 & 0.454 & 21 & 29.6 \\
\hline & Error & 1.75 & 0.577 & 27 & 38.0 \\
\hline
\end{tabular}

\begin{tabular}{|c|c|c|c|c|c|}
\hline $\begin{array}{l}\text { our } \\
\text { knowledge }\end{array}$ & Correct & 1.61 & 0.491 & 44 & 62.0 \\
\hline \multirow{2}{*}{ If } & Error & 1.75 & 0.500 & 26 & 36.6 \\
\hline & Correct & 1.63 & 0.487 & 45 & 63.4 \\
\hline \multirow{2}{*}{ more likely } & Error & 1.50 & 0.500 & 35 & 49.3 \\
\hline & Correct & 1.51 & 0.504 & 36 & 50.7 \\
\hline \multirow[b]{2}{*}{ Can } & Error & 1.25 & 0.503 & 35 & 49.3 \\
\hline & Correct & 1.52 & 0.504 & 36 & 50.7 \\
\hline \multirow{4}{*}{$\begin{array}{l}\text { little } \\
\text { evidence }\end{array}$} & Error & 1.25 & 0.500 & 46 & 64.8 \\
\hline & Correct & 1.36 & 0.483 & 25 & 35.2 \\
\hline & Error & & & $51.3 \%$ & \\
\hline & Correct & & & $48.7 \%$ & \\
\hline
\end{tabular}

\section{Phrases Percent (Total)}

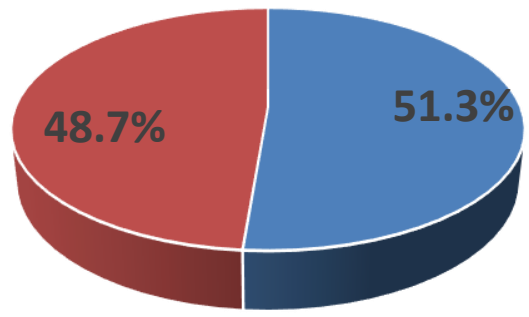

- Error - Correct

\section{Figure 1: The total percent for the uncertain group}

From table 2, it is concluded that:

- The highest correct answer percentage was towardscertain3 $(94.4 \%)$ with a high mean (2.00), while the error answer percentage was (5.6\%) towards the same situation. This indicates that the respondents are more accurate in terms of (certain3) than the others.

- The lowest correct answer percentage was towards certain18 (30.9\%) with a low mean (1.33), while the error answer percentage was (69.1\%) towards the same situation. This indicates that the respondent's accuracy in term of (certain18) is the lowest among the others.

- The total percentage for Error in the 'certain' was 
(55.9\%), and for Correct was (44.1\%). This indicates that the participants in the study do not recognize certainty in the correct way.

Table 2: Certain' Group Descriptive Statistic's

\begin{tabular}{llllll}
\hline \hline & & Mean & STD & Frequency & Percent \\
\hline \multirow{2}{*}{ Certain 3 } & Error & 1.00 & 0.000 & 4 & 5.6 \\
& Correct & 2.00 & 0.000 & 67 & 94.4 \\
\hline \multirow{2}{*}{ Certain 8 } & Error & 1.00 & 0.000 & 36 & 50.7 \\
& Correct & 1.50 & 0.503 & 35 & 49.3 \\
\hline \multirow{2}{*}{ Certain } & Error & 1.50 & 0.577 & 36 & 50.7 \\
13 & Correct & 1.49 & 0.504 & 35 & 49.3 \\
\hline \multirow{2}{*}{$\begin{array}{l}\text { Certain } \\
18\end{array}$} & Error & 1.00 & 0.000 & 49 & 69.1 \\
Total & Correct & 1.33 & 0.473 & 22 & 30.9 \\
Percent & Corror & & & $55.9 \%$ & \\
\hline \hline
\end{tabular}

\section{Certain Percent (Total)}

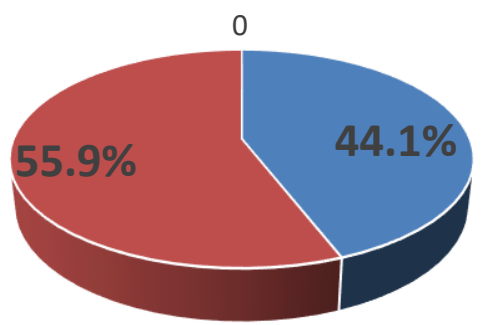

- Correct Error

Figure 2: The total percent for the certain group

The Differences

Table 3: ANOVA Test for 'Uncertain' Groups

\begin{tabular}{llllll}
\hline \hline & $\begin{array}{l}\text { Sum of } \\
\text { Squares }\end{array}$ & Df & $\begin{array}{l}\text { Mean } \\
\text { Square }\end{array}$ & F & Sig. \\
\hline $\begin{array}{l}\text { Between } \\
\text { Groups }\end{array}$ & 10.048 & 13 & .773 & 3.179 & .000 \\
\hline $\begin{array}{l}\text { Within } \\
\text { Groups }\end{array}$ & 238.282 & 980 & .243 & \\
\hline Total & 248.330 & 993 & & \\
\hline \hline
\end{tabular}

From ANOVA for 'uncertain' group table, it is concluded that there are differences between the 'uncertain' groups (14 uncertainty) according to the calculated sig. which is smaller than the default sig. of the study (0.05). This conclusion is confirmed by the value of(F) (3.179) which was greater than its tabulated value (1.730) with degrees of freedom $(13,980)$. To find out the differences between the 'uncertain' groups, it is necessary to refer to the Post Hoc tests.

From Post Hoc table, it becomes evident that the differences were confined to those between the believe phrase, and each of our knowledge phrase and if clause, according to the significance values of the Scheffe test, which were (0.017) and (0.029), respectively, To find out which of these three hedging devises were the main reason for these differences, analysis depended on the values of their means, and as the mean of the if clause (1.63) was larger than the other hedging devices means, this indicates that if phrase is more important than the rest of the hedging devices, and it is followed in order by our knowledge phrase, believe phrase, and so on with the other hedging devices. It is concluded that the respondents' use of the if clause is better than the rest of the hedging devices in the study.

Table 4: Post Hoc Test for 'Unertain' Groups Scheffe

\begin{tabular}{cccccccccccccccc}
\hline \hline & 1 & 2 & 3 & 4 & 5 & 6 & 7 & 8 & 9 & 10 & 11 & 12 & 13 & 14 & Means \\
\hline 1 & - & & & & & & & & & & & & & 1.45 \\
\hline 2 & 1.000 & - & & & & & & & & & & & 1.56 \\
\hline 3 & 1.000 & .989 & - & & & & & & & & & & & 1.39 \\
\hline 4 & 1.000 & .977 & 1.000 & - & & & & & & & & & 1.38 \\
\hline 5 & 1.000 & .999 & 1.000 & 1.000 & - & & & & & & & & 1.44 \\
\hline 6 & .998 & 1.000 & .957 & .925 & .995 & - & & & & & & & & 1.59 \\
\hline 7 & 1.000 & 1.000 & .998 & .995 & 1.000 & 1.000 & - & & & & & & 1.54 \\
\hline 8 & 1.000 & 1.000 & .995 & .989 & 1.000 & 1.000 & 1.000 & - & & & & & 1.55 \\
\hline 9 & .995 & .656 & 1.000 & 1.000 & .998 & .466 & .818 & .743 & - & & & & 1.30 \\
\hline 10 & .989 & 1.000 & .879 & .818 & .977 & 1.000 & 1.000 & 1.000 & .029 & - & & & \\
\hline 11 & .977 & 1.000 & .818 & .743 & .957 & 1.000 & 1.000 & 1.000 & .017 & 1.000 & - & & & 1.62 \\
\hline 12 & 1.000 & 1.000 & 1.000 & .999 & 1.000 & 1.000 & 1.000 & 1.000 & .925 & 1.000 & .999 & - & & 1.51 \\
\hline 13 & 1.000 & 1.000 & 1.000 & .999 & 1.000 & 1.000 & 1.000 & 1.000 & .925 & 1.000 & .999 & 1.000 & - & 1.51 \\
\hline 14 & 1.000 & .925 & 1.000 & 1.000 & 1.000 & 818 & .977 & .957 & 1.000 & .656 & .562 & .995 & .995 & - & 1.35 \\
\hline \hline
\end{tabular}

Table 5: ANOVA Test for 'Certain' Groups

\begin{tabular}{lllllll}
\hline \hline & $\begin{array}{l}\text { Sum } \\
\text { Squares }\end{array}$ & Df & Square & F & Sig. \\
& Squan & & \\
\hline Between Groups & 15.532 & 3 & 5.177 & 26.623 & .000 \\
\hline Within Groups & 54.451 & 280 & .194 & & \\
\hline Total & 69.982 & 283 & & & & \\
\hline \hline
\end{tabular}

From ANOVA for certain groups table, it is concluded 
that there are differences between the four groups (certain3, certain8, certain13, certain18) according to the calculated sig. which is smaller than the default sig. of the study (0.05). This conclusion is confirmed by the value of(F) (26.623) which was greater than its tabulated value (2.637) with degrees of freedom (3, 280). To find out the differences between the four groups, it is necessary to refer to the Post Hoc tests.

Table 6: Post Hoc Test for 'Certain' Groups - Scheffe

\begin{tabular}{llllll}
\hline \hline & Certain3 & Certain8 & Certain13 & Certain18 & Means \\
\hline Certain3 & - & - & - & - & 1.94 \\
\hline Certain8 & 0.000 & - & - & - & 1.49 \\
\hline Certain13 & 0.000 & 1.000 & - & - & 1.49 \\
\hline Certain18 & 0.000 & 0.108 & 0.108 & - & 1.31 \\
\hline \hline
\end{tabular}

From Post Hoc table, it becomes evident that the differences were confined to those between the certain3 and each of the certain8, certain13, and certain18, according to the significance values of the Scheffe test, which were $(0.000),(0.000)$, and (0.000) respectively, To find out which of these four groups was the main reason for these differences, the analysis depended on the values of their means, and as the mean of certain3 (1.94) was larger than the other groups means, this indicates thatcertain 3 is more important than the rest of the groups, and it is followed in order bycertain8, certain13, and certain18 groups.

\section{Findings}

The findings of this study show that the recognition of the final year students from the College of Dentistry of the semantic/ pragmatic function of hedges is not satisfactory. The total percentage of their correct answers in the 'uncertain' group was (48.7\%) as compared to of their incorrect ones, (51.3\%). With regard to the 'certain' group, their performance is even lower. The total percent for their correct answers was $(44.1 \%)$ in comparison to that of their incorrect ones, (55. 9\%).The findings indicate that they are unable to recognize neither uncertainty nor certainty correctly.
The study has also reached the following findings:

- The respondents' accuracy in terms of (if clause) is the highest, whereas their accuracy in terms of (believe) is the lowest among the others.

- The respondents' use of the if clause is better than the rest of the hedging devices in the study.

- The respondents 'accuracy in terms of (certain3) is the highest, while their accuracy in (certain18) is the lowest among the others.

- The respondents' use of(certain3) is better than the rest of the study groups.

\section{Discussion of Results}

The present research aimed to examine the dentistry students' recognition of the use of hedging device. The results show that the respondents' ability to recognize hedging devices varies. This may be an indication that the respondents are more familiar with one hedging device rather than the other. The finding of the present study supports the results of previous research reporting that the majority of Iraqi EFL college students in the fourth year have been found to face difficulties in identifying hedging device at the recognition level (Mukheef,2012).

\section{Conclusions}

The present study aimed at examining Dentistry College final year students' recognition of the semantic/ pragmatic function of hedges in English scientific writing. It was found out that they are unable to recognize uncertainty satisfactorily. This finding answers the research question of the study. This shows that even though the participants are supposed to be advanced students who have been receiving instruction in scientific English for five years, they are still unable to deal with such an important aspect of scientific English namely hedges. The conclusion is that these students face difficulties in the recognition of hedges in English scientific writing. The implication this conclusion has for the present study is that students in this college need an explicit instruction in 
English scientific writing to improve their performance.

\section{Implications}

The implication is that the teaching staff in the dentistry college needs to include academic/ scientific writing in the teaching curricula because according to the conclusions of this study advanced students face difficulties in the recognition of hedges in English scientific writing.

\section{Recommendations}

The findings of the study have inspired the researcher to suggest further research in hedging. A study that involves other scientific colleges is needed to test their students' production of hedges to see to what extent their production corresponds to English scientific writing. This can be done by inspecting the students' research papers. Another study can in fact test the instructors' English scientific writing to see to what extent are the instructors aware of the use and function of hedges.

\section{References}

1. Adamczyk, M. (2015). Do hedges always hedge? On non-canonical multifunctionality of jakby in Polish. Pragmatics, 25(3), 321-344.

2. Banks, D. (1998). Vague quantification in the scientific journal article. ASP. La Revue du Geras, (19-22), 17-27.

3. Brown, P., \& Levinson, S. C. (1987). Some universals in language usage politeness. Cambridge: Cambridge University Press.

4. Cabanes, P. P. (2007). A contrastive analysis of hedging in English and Spanish architecture project descriptions. Revista Española de Lingüística Aplicada, (20), 139-158.

5. Caffi, C. (2007). Mitigation. Amsterdam (ua): Elsevier.

6. Clemen, G. (1997). The concept of hedging: Origins, approaches and definitions. Research in text theory, 235248.

7. Fraser, B. (1975). Hedged performatives. In Speech acts (pp. 187-210). Brill.

8. Fraser, B. (2010). Hedging in political discourse. OKULSKA, U., CAP., Perspectives in Political Discourse, capitolo, 8.

9. Halliday, M. A. K. (1978). Language as Social Semiotic: The Social Interpretation of Language and Meaning. Maryland: University Park Press. http://library.lol/main/C67598B8BE85FF6DE503246E 07C7E74E
10. Hinkel, E. (2005). Hedging, inflating, and persuading in L2 academic writing. Applied Language Learning, 15(1/2), 29.

11. Hyland, K. (1994). Hedging in academic writing and EAP textbooks. English for Specific Purposes-Elmsford and Oxford, 13, 239-239.

12. Hyland, K. (1995). The author in the text: Hedging scientific writing. Hong Kong papers in linguistics and language teaching, 18, 33-42.

13. Hyland, K. (1996a). Talking to the academy: Forms of hedging in science research articles. Written communication, 13(2), 251-281.

14. Hyland, K. (1996b). Writing without conviction? Hedging in science research articles. Applied linguistics, 17(4), 433-454.

15. Hyland, K. (1998). Hedging in scientific research articles (Vol. 54). Amsterdam: John Benjamins Publishing.

16. Hyland, K. (2000). Hedges, boosters and lexical invisibility: Noticing modifiers in academic text. Language Awareness, 9(4), 179-197.

17. Hyland, K. (2008). Persuasion, interaction and the construction of knowledge: Representing self and others in research writing. International Journal of English Studies, 8(2), 1-23.

18. Lakoff, G. (1975). Hedges: A study in meaning criteria and the logic of fuzzy concepts. In Contemporary research in philosophical logic and linguistic semantics (pp. 221-271). Springer, Dordrecht.

19. Lee, M. (2020). Hedges and boosters: L1 and L2speakers' comprehension and production (Doctoral dissertation, San Francisco State University).

20. Mahmood, M. (2018). Semantic and Syntactic Realizations of Hedging in Introductions of Written Academic Discourse. University-Erbil Scientific Journal, (1), 23-36.

https://cuesj.cihanuniversity.edu.iq/2018/08/22/sem antic-and-syntactic-realizations-of-hedging-inintroductions-of-written-academic-discourse/

21. Martín, P. M. (2008). The mitigation of scientific claims in research papers: A comparative study. International Journal of English Studies, 8(2), 133-152.

22. Mukheef, R. N. (2012). Investigating knowledge and use of Iraqi EFL university learners of hedging devices. Journal of University of Babylon, 20(3), 745-779.

23. Prince, E. F., Frader, J. R., \& Bosk, C. (1982). On hedging in physician-physician discourse. En J. di Prieto (ed.), Linguistics and the Professions, 83-97.

24. Rabab'ah, G. (2013). Hedging in nursing and education academic articles. Education, Business and Society: Contemporary Middle Eastern Issues, 6,195-215.

25. Salager-Meyer, F. (1994). Hedges and textual communicative function in medical English written discourse. English for Specific Purposes, 13(2), 149-170.

26. Salager-Meyer, F. (1997). I think that perhaps you should: A study of hedges in written scientific discourse. Functional approaches to written text: Classroom applications,

105-118.https:/ / www.tesol- 
france.org/uploaded_files/files/TESOL $\% 20$ V2N2\%20 C8\%20I\%20think\%20that\%20Perhaps.pdf

27. Skelton, J. (1988). The care and maintenance of hedges. ELT journal, 42(1), 37-43.

28. Varttala, T. (2001). Hedging in scientifically oriented discourse. Exploring variation according to discipline and intended audience. Tampere University Press.

\section{Data for the Questionnaire}

1. Bongelli, R., Riccioni, I., Burro, R., \& Zuczkowski, A. (2019). Writers' uncertainty in scientific and popular biomedical articles. A comparative analysis of the British Medical Journal and Discover Magazine. PloS one, 14(9), e0221933.

2. Carter-Thomas, S., \& Rowley-Jolivet, E. (2008). Ifconditionals in medical discourse: From theory to disciplinary practice. Journal of English for Academic Purposes, 7(3), 191-205.

3. Chavez, T. D. F. (2004). The Language of Uncertainty in a New Illness: Hedging and Modality in the Biomedical Discourse of Severe Acute Respiratory Syndrome (SARS). Mahidol University.

4. Csongor, A. (2013). Rhetorical Moves and Hedging in Medical Research Articles and their Online Popularizations (Doctoral dissertation, Doctoral Dissertation, University of Pécs, Faculty of Health Sciences Doctoral School of Health Sciences. 2013. Available from: http://ltsp. etk. pte. hu/portal/wp/File/Doktoriiskola/Tezisfuzetek/Cson gorA_dissz.pdf).

5. Greig, S. L., \& Deeks, E. D. (2015). Abacavir/dolutegravir/lamivudine single-tablet regimen: a review of its use in HIV-1 infection. Drugs, 75(5), 503514.https://link.springer.com/article/10.1007/s40265$\underline{015-0361-6}$

6. Hanauer, D. A., Liu, Y., Mei, Q., Manion, F. J., Balis, U. J., \& Zheng, K. (2012). Hedging their mets: the use of uncertainty terms in clinical documents and its potential implications whensharing the documents with patients. In AMIA Annual SymposiumProceedings (Vol. 2012, p. 321). American Medical Informatics Association.

7. Hykes, J. M. (2000). A comparison of the use of modal verbs in research articles by professionals and nonnative speaking graduate students, 52 . https://lib.dr.iastate.edu/cgi/viewcontent.cgi?article= 8928\&context $=$ rtd

8. Torgersen, S., Kringlen, E., \& Cramer, V. (2001). The prevalence of personality disorders in a community sample. Archives of general psychiatry, 58(6), 590 .https://jamanetwork.com/journals/jamapsychiatry/a rticle-abstract/481789

9. VOA Learning English. (2011). An 'Image Problem' for a Food that Could Save African Lives. Environment $\mathcal{E}$ Science.https://learningenglish.voanews.com/a/animage-problem-for-a-food-that-could-save-africanlives-112822614/112150.html 
Academic Journal of Nawroz University (AJNU), Vol.10, No.2, 2021 


\title{
Appendix A
}

\author{
University of Duhok/ college of Dentistry \\ Under graduate Studies
}

Please read and evaluate the following statements by choosing either certain or uncertain.

\begin{tabular}{|c|c|}
\hline $\begin{array}{l}\text { 1. "Such a measure might be more sensitive to change in health after specialist } \\
\text { treatment". }\end{array}$ & $\begin{array}{l}\text { The author is: } \\
\begin{aligned} \bullet & \text { certain } \\
\bullet & \text { uncertain }\end{aligned}\end{array}$ \\
\hline $\begin{array}{l}\text { 2- "Concerns that naturally low cholesterol levels could lead to increased morality } \\
\text { from other causes may well be unfounded". }\end{array}$ & $\begin{array}{ll}- & \text { certain } \\
\text { - } & \text { uncertain } \\
\end{array}$ \\
\hline 3- "There is a relationship between smoking and lung cancer". & $\begin{array}{ll}- & \text { certain } \\
\text { - } & \text { uncertain } \\
\end{array}$ \\
\hline $\begin{array}{l}\text { 4- "Without specific training, medical students communication skills seem to decline } \\
\text { during medical training". }\end{array}$ & $\begin{array}{ll}- & \text { certain } \\
\text { - } & \text { uncertain } \\
\end{array}$ \\
\hline $\begin{array}{l}\text { 5- "In spite of its limitations, our study appears to have a number of important } \\
\text { strengths". }\end{array}$ & $\begin{array}{ll}\text { - } & \text { certain } \\
\text { - } & \text { uncertain }\end{array}$ \\
\hline 6- "Fever is present in about a third of cases". & $\begin{array}{ll}- & \text { certain } \\
\text { - } & \text { uncertain }\end{array}$ \\
\hline 7- "Persistent subjective fatigue generally occurs in relative isolation". & $\begin{array}{ll}- & \text { certain } \\
\text { - } & \text { uncertain } \\
\end{array}$ \\
\hline $\begin{array}{l}\text { 8- "People without blood pressure measurement during one year of follow up were } \\
\text { dropped from the blood pressure analysis". }\end{array}$ & $\begin{array}{ll}- & \text { certain } \\
\text { - } & \text { uncertain }\end{array}$ \\
\hline $\begin{array}{l}\text { 9- "Possibly the setting of the neural mechanisms responsible for this sensation is } \\
\text { altered in patients with chronic fatigue syndrome ". }\end{array}$ & $\begin{array}{ll}- & \text { certain } \\
\text { - } & \text { uncertain }\end{array}$ \\
\hline $\begin{array}{l}\text { 10- "This is probably due to the fact that Greenland Eskimos consume diets with a } \\
\text { high content of fish". }\end{array}$ & $\begin{array}{ll}- & \text { certain } \\
\text { - } & \text { uncertain } \\
\end{array}$ \\
\hline $\begin{array}{l}\text { 11- "We believe that the chronic fatigue syndrome reflects a complex interaction of } \\
\text { several factors". }\end{array}$ & $\begin{array}{ll} & \text { certain } \\
- & \text { uncertain }\end{array}$ \\
\hline $\begin{array}{l}\text { 12- "To our knowledge, no previous studies of personality disorder (PhDs) in a large } \\
\text { number representative sample of the common population have been conducted ". }\end{array}$ & $\begin{array}{ll} & \text { certain } \\
\text { - } & \text { uncertain } \\
\end{array}$ \\
\hline $\begin{array}{l}\text { 13- "Abacavir/Lamivudine does not reduce the risk of passing the infection to } \\
\text { others". }\end{array}$ & $\begin{array}{ll}- & \text { certain } \\
- & \text { uncertain }\end{array}$ \\
\hline $\begin{array}{l}\text { 14- "If } 10 \% \text { or more of the malignant nuclei were stained, the slide was scored as } \\
\text { negative". }\end{array}$ & $\begin{array}{ll}- & \text { certain } \\
\text { - } & \text { uncertain } \\
\end{array}$ \\
\hline $\begin{array}{l}\text { 15- "People taking thiazides were more likely to be female and older than } \\
\text { hypertension drugs, while people taking ACEI/ARB group had a higher prevalence } \\
\text { of myocardial infarction, heart failure and diabetes". }\end{array}$ & $\begin{array}{ll}- & \text { certain } \\
- & \text { uncertain }\end{array}$ \\
\hline $\begin{array}{l}\text { 16- "Translocation of fixed carbon away from source tissue can reduce feedback } \\
\text { inhibition of photsynthesis resulting from photsynthate accumulation under high } \\
\text { carbon dioxide". }\end{array}$ & $\begin{array}{ll}- & \text { certain } \\
- & \text { uncertain }\end{array}$ \\
\hline 17- "I can find little evidence that the thyroid is the source of her cancer". & $\begin{array}{ll}- & \text { certain } \\
\text { - } & \text { uncertain } \\
\end{array}$ \\
\hline $\begin{array}{l}\text { 18- "The World Health Organization links vitamin A deficiency to... two hundred } \\
\text { fifty thousand child deaths every year". }\end{array}$ & $\begin{array}{ll} & \text { certain } \\
\text { - } & \text { uncertain } \\
\end{array}$ \\
\hline
\end{tabular}

Statements 1,2,4,5,6,7,8,9, 10, and 11 were taken fromSalager-Meyer, F. (1997); 3 fromBongelli, R., Riccioni, I., Burro, R., \& Zuczkowski, A. (2019); 12 from Torgersen, S., Kringlen, E., \& Cramer,

V. (2001); 13 fromGreig, S. L., \& Deeks, E. D. (2015); 14 from Carter-Thomas, S., \& Rowley-Jolivet, E. (2008); 15 fromCsongor, A. (2013); 16 fromHykes, J. M. (2000); 17 from Hanauer, D. A., Liu, Y., Mei, Q., Manion, F. J., Balis, U. J., \& Zheng, K. (2012); 18fromVOA Learning English. (2011). 


\section{Appendix B}

Jury members

The following members have evaluated and validated the questionnaire:

\begin{tabular}{|l|l|l|}
\hline Name & Affiliation & Scientific title \\
\hline Dr. Shivan S. Toma & $\begin{array}{l}\text { College of languages, } \\
\text { University of Duhok }\end{array}$ & Assistant Professor \\
\hline Dr. Haveen & College of languages, & Assistant Professor \\
& University of Duhok & \\
\hline Dr. Parween & College of languages, & Assistant Professor \\
& University of Duhok & \\
\hline
\end{tabular}

